\title{
Development of Participation-Collaboration-Based Football Community Media in Indonesia: Issues and Conditions in Editorial Room
}

\author{
$1^{\mathrm{s}{ }^{*}}$ Fajar Junaedi \\ Department of Communication Science \\ Universitas Muhammadiyah Yogyakarta \\ Yogyakarta, Indonesia \\ fajarjun@umy.ac.id
}

\author{
$2^{\text {nd }}$ Filosa Gita Sukmono \\ Department of Communication Science \\ Universitas Muhammadiyah Yogyakarta \\ Yogyakarta, Indonesia \\ filosa@umy.ac.id
}

\begin{abstract}
The football supporters in Indonesia frequently experience negative stigma from mainstream media, mainly when violence concerning football occurs. The supporters become media convicts and are covered as the cause of violence in the football world. Against this stigma, community media, which are managed by the football supporters, emerge in several cities like in Sleman, Surabaya, Jakarta, and Bandung. The community media that are organized by the football supporters prove that their negative stigma, as labeled by mainstream media, should be reconsidered. The existence of community media shows the development of football literacy in the circle of football fans. Granted, the football community media also experience some issues. This research aims to map the issues and the conditions of football community media's editorial room in Sleman, Surabaya, Jakarta, and Bandung. This research shows that the development model of supporter-based football community media in Indonesia is characterized by four main features. Firstly, the utilization of the internet platform as a community media. Secondly, the analysis and review of the match as the superior content. Thirdly, the involvement of fans as the contributor content, which can be seen as a supporters' journalism, and of readers to finance the continuity of community media through selling merchandise and donation by crowdfunding scheme. The collaboration among community media, fans, and club management is very significant in developing the football supporters' media community in Indonesia. Furthermore, the participation of football supporters to support community media becomes capital in developing the community media in Indonesia.
\end{abstract}

Keywords - Community media, football supporters/fans, media management, and collaboration

\section{INTRODUCTION}

After 1998, there were two major changes in Indonesia's media blueprint, namely, first, the changing of the political system from New Order to Reformation Era, which opened the freedom of the press, and, second, the advancement of technology, particularly the availability of digital technology. Through digital technology, the production of messages for the audience is not through mass communication and not just dominated by press companies. A community can also establish media for its audience. Community media is assumed to be more capable of fulfilling the audience's needs. The necessity of the audience is often considered the necessity of the majority of the audience and reduced to everything the audience wants, whereas the wants of the audience (public wants) are not necessarily the needs of the audience (public needs) [1].

The rapid development of media, primarily the commercial media that are operated by private companies, do not satisfy the necessity of football supporters in some cities in Indonesia. The live broadcast of football matches on television, the news of local football in local newspapers, and the specific websites containing football news are not capable of fulfilling the necessity of local football fans concerning the information of football club that they support. Therefore, some community media emerge in order to precisely fulfill the necessity of local football club supporters in Indonesia, like Sleman Football in Sleman, Emosi Jiwaku in Surabaya, Simamaung in Bandung, and Sepakbola Jakarta in Jakarta.

The emergence of football fans' community media is an opportunity to develop supporters' literacy and as a football media startup. Some research about this topic has been performed by Fajar Junaedi [2] and Andy Fuller [3]. Both researchers showed that football fans are frequently stigmatized negatively by mainstream media, particularly regarding the violence that involves the football supporters. The generalization that is exercised by mainstream media toward football supporters in the frame of negative news places the football supporters as a convict. The issues of this negative stigma can be minimized by developing literacy, primarily through developing community media managed by football fans.

This research aims to map the issues faced by football community media in Sleman, Surabaya, Bandung, and Jakarta. This research is a necessity, as an effort of media literacy in the circle of football supporters in Indonesia. This community media management study is beneficial for and can be adopted by football supporters' media community in other cities in Indonesia.

\section{LITERATURE REVIEW}

Football fans are the consumer for mass media to gain the audience, so that sport is one of the significant issues in media. Media, both printed and electronic media, reports incessantly when a famous club (national/international) is showing its 
strength in the match. It cannot be denied that, up to now, football still becomes favorite news in media. This is because football supporter has a higher number than other sports. The news about the sports world is not only reported by media when the match is still going on, but also when there is nothing match. The topics about the player profile, player activity, player transfer at a club, for instance, are incessantly reported in media[4].

A sport rubric, ultimately, becomes one of the vital topics in media. Boyle[5] stated that, according to journalism history in the United States of America, sports journalism was wellknown as a 'toy department,' a bastion of easy living, sloppy journalism, and 'soft' news. It means that sports news is not difficult news, but soft and easy news like a game.

There was some previous research about football community media. Hasby [6] has researched the community media of PSIM Yogyakarta fans entitled "Bawah Skor dan Parang Biru" and found that a community media organized by youth outside club management experienced inconsistency in accommodating the news during its development. Hasby [6] also researched Elja Radio, a community radio managed by PSS Sleman supporters. This radio utilized internet steaming to conduct its broadcast. The research found that Elja Radio has developed into a small and medium enterprise (UKM).

The next research about football fans community media was conducted by Laily and Ramdhon [7] about a community media managed by Pasoepati, an organization of football club supporters from Solo. The finding of the research showed that Pasoepati.net site informed the news about football in Solo, Pasoepati, and national football. Aside from being an online site, Pasoepati.net also published a digital magazine, namely PasoepatiNet Digital Magazine.

Another research is about football community management in Yogyakarta city, Sleman, Surakarta, and Surabaya, which was conducted by Arifianto and Junaedi [8]. This research found that football community media was established due to the same culture, purposes, and interests in collective life in society. The characters owned by a community media, as has been mentioned above, enable to maintain the empathy between media (media manager) and public members of the community because both media managers and community members possess similar cultural orientation and purposes.

\section{METHOD}

This research applied a case study research method. This method opted because it can answer qualitative formulations and formulation of the problems holistically and exhaustively. The technique used was an exploration of the activities of the managers of football community media. By an observation technique, document analysis, literature review, in-depth interview, and focus group discussion (FGD) will be inseparable parts which then be combined by snowball technic as a mechanism to determine the informants [9].

The observation was conducted by observing the football community media and its editorial room profoundly. The implementation of the document analysis and literature review method was by studying documents and literature about community media, football fans, and Indonesia football. The characteristics of the in-depth interview conducted in this research were flexible, open, do not have a tight structure, are not in a formal situation, and can be done repeatedly on informants [10]. In choosing informants, this research applies purposive sampling or criterion-based selection. The collected data will be analyzed. The data analysis is a process to arrange the data order and organize it into a definite pattern, category, and description. In this phase, the data was processed with an aim to describe a situation clearly and precisely [9]. The data analysis is exercised with data triangulation obtained from observation, document analysis, literature review, deep interview, and FGD. Those data were processed in order to answer the formulation of problems in this research.

\section{RESULT AND DISCUSSION}

Football and fans are two parts that are related to each other. Football has changed human rational thought 'till infatuate. Human's love for a football club that they support proves the loyalty of supporters. The availability of football's flags and banners in every street corner becomes a symbol and identity of them [11].

The football fans need information relates to a club that they support. Before the popularity of the internet happens, football fans gained information through mainstream media like radio, television, and print media (newspaper, magazine, and tabloid). The emerging internet has become an essential competitor to traditional sports media and in the context of the evolution of communication.

The Internet is a medium that provides the consumers' proximity. If a consumer wants to access match results, the internet is the answer [12]. This distinguishes the internet from printed media that publishes at least once a day. Different from television that has a high cost in its production, the production cost for the news on the internet is not high.

For football supporters, the internet becomes a new way to manage community media. Comparing with broadcasting media and printed media that needs high cost, the internet is more reached out.

\section{A. The Problems of Football Community Media}

Relatively, community media based on football fans own identical aim, those are education and literacy for each club fans. Pawito stated that four roles of community media could be developed. Those are: first, distributing information and knowledge; second, facilitating public discussion forum concerning the problems of community members and other more significant problems like the interaction between community members and society and even national problems; third, helping to reach agreement in order to overcome the problems; and fourth, encouraging the spirit of participation [13].

Generally, the main obstacle in the editorial management of football fans community media is the availability of the news to fill the rubrics. It is different from mainstream media that own its professional journalist. The community media is mostly managed by part-time journalists who work based on their loyalty and devotion to the club. This becomes a problem to guarantee the sufficiency of the content in football community media.

The other problem faced by football fans community media is the intervention from club management and the refusal from fellow football supporters because there is news 
assumed as not appropriate with their voice. Therefore, independence becomes one of the greatest threats faced by football fans community media. Pasoepati Net established its independence by not becoming a part of Persis Solo club management, although some journalists became part of the club management.

Another problem that arises is about participation. The essence of citizen participation in citizen journalism is to provide independent, reliable, accurate, comprehensive, and relevant information that is needed in a democracy. However, because the journalists in citizen journalism are not usually trained professionally -or they do not own this intention-not all contributions from citizen journalists obey the ethic standard of professional journalists. Moreover, citizen journalists typically give their perspective and frequently biased in seeing the phenomena [14]. This becomes an issue when the community media reports the rivalry among clubs. This loyalty and devotion engender the news produced personal and partisan to the club that is supported.

Each football community media has its various situations in its editorial room to deal with those obstacles. The following is a map of the situation in the editorial room of a football fan-based community media.

TABLE I. TABLE TyPE Styles

\begin{tabular}{|c|c|c|c|}
\hline No & Media Name & Situation & Website \\
\hline \multirow[t]{3}{*}{1.} & \multirow[t]{3}{*}{$\begin{array}{l}\text { Sleman } \\
\text { Football }\end{array}$} & $\begin{array}{l}\text { Receiving straight news from } \\
\text { communities }\end{array}$ & \multirow{3}{*}{$\begin{array}{l}\text { https://slem } \\
\text { an- } \\
\text { football.co } \\
\mathrm{m} /\end{array}$} \\
\hline & & $\begin{array}{l}\text { The opinions/articles are } \\
\text { usually written by PSS } \\
\text { Sleman supporters, who are } \\
\text { workers. }\end{array}$ & \\
\hline & & $\begin{array}{l}\text { Selecting issue through } \\
\text { Twitter }\end{array}$ & \\
\hline \multirow[t]{4}{*}{2.} & \multirow[t]{4}{*}{$\begin{array}{l}\text { Emosi } \\
\text { Jiwaku }\end{array}$} & $\begin{array}{l}\text { Adjusting the writing style in } \\
\text { order to be easily understood } \\
\text { by the readers. For example, } \\
\text { in writing tactic uses simple } \\
\text { languages and vocabularies. }\end{array}$ & \multirow[t]{4}{*}{$\begin{array}{c}\text { https://emo } \\
\text { sijiwaku.co } \\
\mathrm{m} /\end{array}$} \\
\hline & & $\begin{array}{l}\text { Citing from conventional } \\
\text { media, particularly Jawa Pos. }\end{array}$ & \\
\hline & & $\begin{array}{l}\text { Presenting the coach's } \\
\text { statement as one of the } \\
\text { interesting issues in the news } \\
\text { for whatever reason said by } \\
\text { the coach must have news } \\
\text { value. }\end{array}$ & \\
\hline & & $\begin{array}{l}\text { Conducting crowdfunding } \\
\text { through "Kitabisa" platform } \\
\text { in order to get funding for the } \\
\text { continuity of community } \\
\text { media. }\end{array}$ & \\
\hline \multirow[t]{3}{*}{3.} & \multirow{3}{*}{$\begin{array}{l}\text { Sepakbola } \\
\text { Jakarta }\end{array}$} & Managed by a team & \multirow{3}{*}{$\begin{array}{c}\text { https://ww } \\
\text { w.sepakbol } \\
\text { ajakarta.co } \\
\mathrm{m} /\end{array}$} \\
\hline & & $\begin{array}{l}\text { Providing information about } \\
\text { football in Jakarta, exactly } \\
\text { Persijak Jakarta, including } \\
\text { match review }\end{array}$ & \\
\hline & & $\begin{array}{l}\text { Giving an opportunity for the } \\
\text { readers to contribute articles }\end{array}$ & \\
\hline \multirow[t]{3}{*}{4.} & \multirow[t]{3}{*}{ Simamaung } & $\begin{array}{l}\text { Well-established in providing } \\
\text { information about Persib } \\
\text { Bandung and its fans }\end{array}$ & \multirow[t]{3}{*}{$\begin{array}{l}\text { https://sima } \\
\text { maung.com }\end{array}$} \\
\hline & & $\begin{array}{l}\text { Creating a Podcast to fill the } \\
\text { necessity of audience. }\end{array}$ & \\
\hline & & $\begin{array}{l}\text { Establishing a store to provide } \\
\text { the merchandise as well as to } \\
\text { get income for the }\end{array}$ & \\
\hline
\end{tabular}

\begin{tabular}{|l|l|l|l|}
\hline No & Media Name & \multicolumn{1}{|c|}{ Situation } & Website \\
\hline & & $\begin{array}{l}\text { sustainability of this } \\
\text { community media }\end{array}$ & \\
\hline
\end{tabular}

Fig. 1. Editorial room's situations of a football fan-based community media

\section{B. Finding the Needs of the Readers}

From a system of media and democracy in Indonesia, the birth and development of community media are a result of the reformation era. Before the reformation era, mass media was strictly controlled by a government. However, the freedom of the press in the reformation era does not always gratify all parties. The media industry makes journalism market-driven journalism, and consequently, the audience is often ignored. When the freedom of the press was opened after 1998, the spirit of the reformation in the sector of media regularly grew in society. Nevertheless, that condition does not guarantee media alignments to the public. The spirit of decreasing government domination is also still encountered with the strong dominance of the market on media [1, p. 1]. The necessity of the public is considered as same as the necessity of the majority. As a result, public necessity is reduced to be the public wants while the public wants are not necessarily the needs of the audience (public needs) [1, pp. 3-4]. What has been exercised by community media can be seen as the wish of football supporters in reporting their club.

In the context of fans and club management, the emerging football fan-based community media creates an anomaly for a football club management. Through community media, the football supporters actively participate in reporting their club. Meanwhile, the official media of the football club, which ideally provide adequate information, does not diffuse report information about the club. Based on loyalty and devotion, football fans exercise journalism practices and football media management. Nevertheless, the collaboration between club management and community media editor should be supported. On the one hand, the club needs a football community media to interact and build relationships with the fans. On the other hand, community media needs access to the club in order to gain new content.

\section{CONCLUSION}

This research has shown that some features characterize the development model of football community media in Indonesia managed by football supporters. Those features are the utilization of internet platform as a community media, the analysis and review of the match as a superior content, the involvement of fans as the contributor content which can be seen as the supporters' journalism, and the involvement of readers to finance the continuity of community media through selling merchandise and donation by crowdfunding scheme. The collaboration among community media, fans, and club management become very significant in developing the football supporters' media community in Indonesia. Furthermore, the participation of football supporters to support community media becomes capital in developing the community media in Indonesia.

\section{ACKNOWLEDGMENT}

The researchers thank LP3M Universitas Muhammadiyah Yogyakarta that funds and enables this research to be realized. 


\section{REFERENCES}

[1] E. Maryani, Media dan Perubahan Sosial: Suara Perlawanan Melalui Radio Komunitas. Bandung: Rosda Karya, 2011.

[2] F. Junaedi, Merayakan Sepakbola: Fans, Identitas dan Media. Yogyakarta: Fandom Indonesia, 2016.

[3] A. Fuller, "Soccer and The City: The Game and Its Fans in Solo dan Yogyakarta," Sport in Society, vol. 20, 2017, doi: 10.1080/17430437.2016.1158470.

[4] O. L. Pramesthi, "Olah Raga, Media dan Audiens: Perspektif Media Lokal dalam Meliput Isu Olahraga," in Sport, Komunikasi dan Audiens: Arena Olah raga dalam Diskursus Ekonomi-Politik, Bisnis, dan Cultural Studies, F. Junaedi, B. Satyabharata, and S. Budi, Eds. Yogyakarta: Aspikom; Fikom Untar; Prodi Ilmu Komunikasi UAJY; Buku Litera, 2014.

[5] R. Boyle, Sport Journalism: Issues and Context. New York: SAGE Publications, 2006

[6] H. Sirajudin, "Merawat Media Komunitas, dalam Hasbi, Sirajudin dan Sasono, Feri Triadi [ed]," in Sepakbola 2.0, Yogyakarta: Football Fandom, 2015.

[7] D. F. Laily and A. Ramdhon, "Media, Dinamika dan Suporter: Catatan untuk Pasoepati," in Sepak Bola 2.0, S. Hasbi and F. T. Sasono, Eds. Yogyakarta: Football Fandom, 2015.
[8] B. D. Arifianto and F. Junaedi, "Berawal Dari Kecintaan, Berproses Dalam Media Komunitas Sepakbola: Menengok Manajemen Media Komunitas Berbasis Fans Sepak Bola," in Mediamorfosa: Transformasi Media di Indonesia, F. Junaedi, Ed. Yogyakarta: ASPIKOM; Buku Litera; UKSW, 2017.

[9] L. J. Moleong, Metodologi Penelitian Kualitatif. Bandung: Remaja Rosdakarya, 2006.

[10] L. Neuman, Social Research Methods: Qualitative and Quantitative Approaches, 4th Edition. Boston: Allyn and Bacon, 2000.

[11] H. P. Santosa, "Olah Raga, Komunikasi dan Multikulturalisme: Dimensi Sosial Sepakbola di Indonesia," in Sport, Komunikasi dan Audiens : Arena Olah raga dalam Diskursus Ekonomi-Politik, Bisnis, dan Cultural Studies, F. Junaedi, S. Bonaventura, and S. Budi, Eds. Yogyakarta: Aspikom; Fikom Untar; Prodi Ilmu Komunikasi UAJY; Buku Litera, 2014.

[12] M. Nicholson, Sport and Medi: Managing the Nexus. Amsterdam: Elsevier, 2007.

[13] P. Pawito, "Pawito, P. (2007). Media Komunitas dan Media Literacy. , 4(2), 102359.," Jurnal Ilmu Komunikasi, vol. 4, no. 2, pp. 167-177.

[14] N. Jurrat, Mapping Digital Media: Citizen Journalism and The Internet. Open Society Media Program and the Open Society Information Program, 2011. 